\title{
Effect of fertilizers, lime and cadmium added to soil on the cadmium content of spring wheat
}

\author{
AnTti JAAKKola \\ Agricultural Research Centre, Department of Agricultural Chemistry and Physics, \\ 01300 Vantaa 30.
}

Abstract. In a pot experiment the cadmium content of wheat grain grown on acid $\left(\mathrm{pHC}_{\mathrm{CaCl}_{2}} 5.5\right)$ loam and clay soils was increased from 55 to $440-540 \mu \mathrm{g} / \mathrm{kg}$ by addition of $1 \mathrm{mg}$ of cadmium per $\mathrm{kg}$ of soil. Raising of NPK fertilization increased the cadmium content of grain in general. The effect of liming varied.

In field experiments the cadmium contents of wheat grain and straw were increased by cadmium addition on loam much more than on clay. Wheat grown on the loam suffered from severe drought. Cadmium application of $100 \mathrm{~g} /$ ha raised the cadmium contents in grain $10-60$ and in straw $10-90 \mu \mathrm{g} / \mathrm{kg}$. The contents were initially in the range $39-69$ $\mu \mathrm{g} / \mathrm{kg}$. In an experiment in which fertilizers with various cadmium contents because of different raw materials were compared, not even the highest addition of cadmium, $49 \mathrm{~g} / \mathrm{ha}$, caused a significant change in the cadmium contents of grain or straw.

\section{Introduction}

The injurious effect of cadmium depends mainly on its ability to accumulate in certain human and animal organs, particularly in the liver and kidneys. In consequence even a moderate amount of cadmium in food may prove serious if the food in question forms the major part of the diet. The cadmium content of cereal grain is therefore particularly interesting, although there are a number of plants that normally contain much more cadmium.

The aim of this study was to collect data on the effect of fertilizers and lime on the cadmium content of spring wheat and on its response to added cadmium.

\section{Material and methods}

The experiments consisted of pot and field experiments. The pot experiment was performed using soils taken from the plough layer of two experimental fields. In addition to these experiments made in 1973, a third field trial was performed in the following year.

The pot experiment was established with two soils:

\begin{tabular}{|c|c|c|c|}
\hline & clay $(<2 \mu \mathrm{m}), \%$ & org. C, \% & $\mathrm{pH}_{\mathrm{CaCl}_{2}}$ \\
\hline Loam $\ldots \ldots \ldots \ldots \ldots \ldots \ldots$ & 22 & 4.9 & 4.6 \\
\hline Clay $\ldots \ldots \ldots \ldots \ldots \ldots \ldots$ & 48 & 3.7 & 5.4 \\
\hline
\end{tabular}


The treatments in four replicates consisted of three factors with the following levels:

L lime application

$\mathrm{L}_{0}$ no lime

$\mathrm{L}_{1} 10 \mathrm{~g}$ of $\mathrm{Ca}(\mathrm{OH})_{2}$ per pot

F fertilizer rate

$\mathrm{L}_{2} 20$, ,

$\mathrm{F}_{1} \mathrm{~N} 0.7, \mathrm{P} 0.45, \mathrm{~K} 0.6 \mathrm{~g}$ per pot $=$ low

$\mathrm{F}_{2} \mathrm{~N} 1.4, \mathrm{P} 0.9, \mathrm{~K} 1.2,,,=$ high

Cd cadmium addition

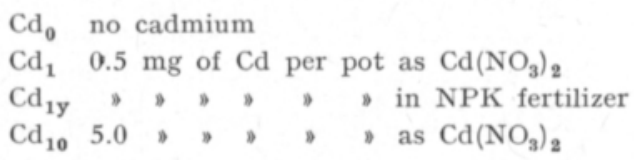

The $\mathrm{Cd}_{1 \mathrm{y}}$ treatment was given as cadmium chloride treated compound fertilizer containing $15 \% \mathrm{~N}, 8.7 \% \mathrm{P}$, and $12.4 \% \mathrm{~K}$. Combined with treatment $\mathrm{F}_{1}$ the fertilizer $(5 \mathrm{~g} / \mathrm{pot})$ contained $100 \mathrm{mg} / \mathrm{kg}$ of $\mathrm{Cd}$ and with $\mathrm{F}_{2}(10 \mathrm{~g} / \mathrm{pot})$ $50 \mathrm{mg} / \mathrm{kg}$ of $\mathrm{Cd}$. The cadmium treatment of the fertilizer was performed by Kemira Co. In the other cadmium treatments $\left(\mathrm{Cd}_{0}, \mathrm{Cd}_{1}\right.$ and $\left.\mathrm{Cd}_{10}\right)$ the $\mathrm{N}, \mathrm{P}$ and $\mathrm{K}$ were given as analytical grade chemicals.

The fertilizers, including, in addition to the above-mentioned nutrients, adequate amounts of $\mathrm{Mg}, \mathrm{Mn}, \mathrm{Cu}, \mathrm{Zn}$ and $\mathrm{B}$, and cadmium nitrate weighed for each pot, were mixed with $5.0 \mathrm{~kg}$ of air-dry soil. The soils in the pots were moistened approximately to field capacity with deionized water. Spring wheat, variety Ruso, was sowed 26-27.3.1973. After sprouting the plants were thinned to twenty per pot. The pots were kept in glasshouse over the whole period of growth. They were watered when necessary to keep the moisture near field capacity. The crop was harvested after a growing time of 92 days at full grain maturity. After threshing, the grain of each pot was weighed and analysed for cadmium. At the end of the experiment the soil $\mathrm{pH}$ in $0.01 \mathrm{M} \mathrm{CaCl}_{2}$ suspension was determined.

The two field experiments from whose plough layer the soils for the pot experiment had been taken were located in southern Finland, one in Hausjärvi (loam soil) and the other in Tuusula (clay soil). In both places a split plot experiment was established. The treatments in the main plots were:

$$
\begin{array}{ll}
\mathrm{L}_{0} & \text { no lime } \\
\mathrm{L}_{1} & 10 \mathrm{t} / \mathrm{ha} \text { of ground limestone }
\end{array}
$$

There were four replicates arranged in separate blocks. In each block the treatments were randomized. The main plots were divided into three subplots having the following randomized treatments:

$$
\begin{array}{ll}
\mathrm{Cd}_{0} & \text { no cadmium added } \\
\mathrm{Cd}_{1} & 100 \mathrm{~g} / \mathrm{ha} \text { of cadmium added in NPK fertilizer } \\
\mathrm{Cd}_{2} & 200 \mathrm{~g} / \mathrm{ha}
\end{array}
$$

The subplots were two square metres in size. The lime was distributed in the spring of the experimental year. It was mixed with the soil to a depth of 
ca. $15 \mathrm{~cm}$ by harrowing. For fertilization $1000 \mathrm{~kg} / \mathrm{ha}$ of a compound fertilizer containing $15 \% \mathrm{~N}, 8.7 \% \mathrm{P}$ and $12.4 \% \mathrm{~K}$ was used. The fertilizers used for the cadmium treated plots had been coated with cadmium chloride by Kemira Co. The cadmium contents of the fertilizers were $100 \mathrm{mg} / \mathrm{kg}\left(\mathrm{Cd}_{1}\right)$ or $200 \mathrm{mg} / \mathrm{kg}$ $\left(\mathrm{Cd}_{2}\right)$. The fertilizer was placed to a depth of $8 \mathrm{~cm}$.

Spring wheat, variety Ruso, was sowed 7.5. (clay soil) and 23. 5.1973 (loam soil). After 95 (clay soil) and 84 (loam soil) days $1.5 \mathrm{~m}^{2}$ of the subplots were harvested by cutting the plants ca. $5 \mathrm{~cm}$ above the soil surface. When threshed, the grain and straw were weighed and samples were taken for chemical analyses.

To get an idea of the practical importance of cadmium containing fertilizers, and in order to compare fertilizers differing in their cadmium sources, a further field experiment was laid out. In this experiment common methods used in practical farming were applied as far as possible. The fertilizer was placed to a depth of $8 \mathrm{~cm}$ into every second $12 \mathrm{~cm}$ space between the sowing rows. The treatments consisted of fertilizations performed with compound fertilizers $(15 \% \mathrm{~N}, 8.7 \% \mathrm{P}$ and $12.4 \% \mathrm{~K})$ differing in their cadmium content and source of cadmium. In all treatments the fertilizer rate was $600 \mathrm{~kg} / \mathrm{ha}$. The treatments were:

1. NPK fertilizer for which Kola apatite was used as phosphorus source, cadmium content of the fertilizer $1.5 \mathrm{mg} / \mathrm{kg}$.

2. NPK fertilizer, made by the Kemira fertilizer manufacturing company in a pilot plant using Kola apatite as phosphorus source. Sulphuric acid used in the process was contaminated with cadmium. Cadmium content $30 \mathrm{mg} / \mathrm{kg}$.

3. NPK fertilizer, made in the pilot plant of Kemira using cadmium containing rock phosphate from Taiba, cadmium content of the fertilizer $57 \mathrm{mg} / \mathrm{kg}$.

4. NPK fertilizer, made in the pilot plant of Kemira using cadmium containing rock phosphate from Taiba as phosphorus source. Extra cadmium was added as chloride. Cadmium content $81 \mathrm{mg} / \mathrm{kg}$.

5. Mixture of fertilizers used for treatments 1 and 3 (49: 51), cadmium content $30 \mathrm{mg} / \mathrm{kg}$.

6. Mixture of fertilizers used for treatments 1 and 4 (65: 35), cadmium content $30 \mathrm{mg} / \mathrm{kg}$.

Each treatment had four replicates situated in separate blocks. The 24 plots were $60 \mathrm{~m}^{2}$ in size. Spring wheat, variety Ruso, was sowed 16. 5. 1974 and harvested with a combine harvester 8.9. The straw of each plot was baled. After weighing the yields samples were taken of grain and straw for determinations of moisture, cadmium and some nutrients.

\section{Analytical methods}

For cadmium determination the plant material was digested by dry ashing at $450^{\circ} \mathrm{C}$. The ash was dissolved in $4 \mathrm{~N} \mathrm{HCl}$. The solution was evaporated to dryness. The residue was dissolved in nitric acid. The cadmium was determined in this solution by flameless atomic absorption (equipment Varian Techtron, CRA-63). For determination of some mineral nutrients in plant material, dry 
ashing at $520^{\circ} \mathrm{C}$ was applied as digestion method. $\mathrm{K}, \mathrm{Ca}$ and $\mathrm{Mg}$ were determined by atomic absorption and $\mathrm{P}$ colorimetrically (vanadate method) in acid extract of the ash.

The analysis of variance was applied for the statistical testing of the results. In order to compare individual treatment means Tukey's test (STEEL and TORRIE 1960) was used.

\section{Results}

\section{The pot experiment}

The grain yield of spring wheat was not affected by cadmium addition to the soil. Consequently only the mean yields over the four cadmium treatments are given in Table 1. In the loam soil the $\mathrm{pH}$ of which was rather low, both liming and raising of fertilizer application increased the yield. The yield increase due to higher fertilization was not clearly dependent on the liming. In the clay soil the only significant effect of the lime was a decrease of yield at the rate of $10 \mathrm{~g} /$ pot, however, only at lower fertilization. Heavier liming raised the yield to the initial level again. Higher fertilization led to a higher yield.

The cadmium content of grain in pots given $5 \mathrm{mg}$ of cadmium varied much more than the content in other pots. For this reason the statistical analysis was performed in separate groups.

Table 1. Yields and cadmium contents of spring wheat grain in the pot experiment.

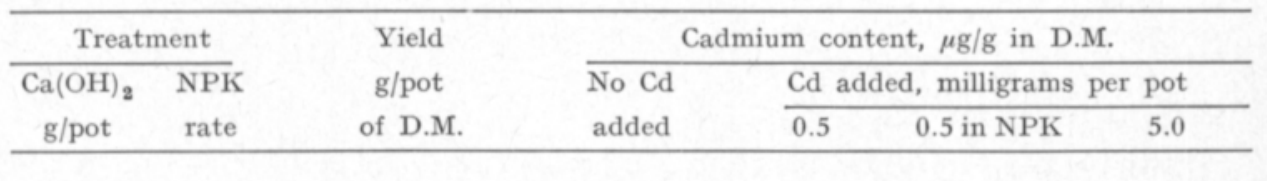

1. Loam soil

\begin{tabular}{|c|c|c|c|c|c|}
\hline low & $33.7^{\mathrm{A}}$ & $59^{a}$ & $119 \mathrm{bc}$ & $117^{b e}$ & $508^{\alpha \beta}$ \\
\hline high & $39.1^{B}$ & $49^{a}$ & $132 \mathrm{ed}$ & $144^{\mathrm{ed}}$ & $558^{\beta}$ \\
\hline \multirow[t]{2}{*}{10} & $39.5^{\mathrm{BC}}$ & $57 \mathrm{a}$ & $118^{\text {be }}$ & $150^{\mathrm{ed}}$ & $444^{\alpha \beta}$ \\
\hline & $42.4^{\mathrm{BC}}$ & $86^{\mathrm{ab}}$ & $140^{\mathrm{ed}}$ & $213^{e}$ & $861 \gamma$ \\
\hline \multirow[t]{2}{*}{20} & $39.0^{\mathrm{B}}$ & $54^{\mathrm{a}}$ & $90^{\mathrm{ab}}$ & $179^{d}$ & $332^{a}$ \\
\hline & $43.4^{\mathrm{C}}$ & $75^{\mathrm{ab}}$ & $141^{\mathrm{ed}}$ & $258^{e}$ & ${ }_{545} \beta$ \\
\hline
\end{tabular}

2. Clay soil

\begin{tabular}{|c|c|c|c|c|c|}
\hline low & $28.9^{\mathrm{BC}}$ & $55^{\mathrm{ab}}$ & $113^{\text {bed }}$ & $111^{\text {bed }}$ & $535 \gamma^{\delta}$ \\
\hline high & $32.0^{\mathrm{CD}}$ & $75^{\text {abe }}$ & $180^{\text {def }}$ & $240^{t}$ & $616^{\delta}$ \\
\hline \multirow[t]{2}{*}{10} & $24.2^{\mathrm{A}}$ & $38^{\mathrm{a}}$ & $72^{\mathrm{abe}}$ & $80^{\text {abe }}$ & $254^{\alpha \beta}$ \\
\hline & $33.1^{\mathrm{D}}$ & $72^{\mathrm{abc}}$ & $134^{\text {ede }}$ & $194^{\text {et }}$ & $667 \delta$ \\
\hline \multirow[t]{2}{*}{20} & $28.3^{B}$ & $37^{a}$ & $105^{\mathrm{abc}}$ & $127^{\text {bed }}$ & $189^{\alpha}$ \\
\hline & $32.4^{\mathrm{D}}$ & $62^{\mathrm{ab}}$ & $143^{\text {ede }}$ & $176^{\text {def }}$ & $405 \beta \gamma$ \\
\hline
\end{tabular}

Yields and their cadmium contents on each soil followed by a common letter do not differ significantly ( $\mathrm{P}=0.05)$ according to Tukey's test. 
No statistically significant differences were observed in grain cadmium contents between the treatments without cadmium addition to the soil. However, a tendency of higher fertilization to increase the content was obvious.

The addition of $0.5 \mathrm{mg}$ of cadmium per pot apparently increased the grain cadmium content in general. However, the differences were not significant in all fertilizing and liming treatments. In the limed loam the cadmium in the commercial NPK fertilizer was more efficient than the same amount added separately. This appeared to be generally so in spite of the significance lacking in the other cases. At the higher fertilizer application, the grain contained more cadmium than at the lower one, however, not always significantly. The cadmium given in NPK fertilizer to the loam warmore efficient when the soil was heavily limed.

The addition of $5 \mathrm{mg}$ of cadmium per pot increased the grain cadmium content very clearly. On the limed soils, higher fertilization led to a larger increase of cadmium content in the grain. On the loam, at the high fertilizer rate, the smaller amount of calcium hydroxide $(10 \mathrm{~g} / \mathrm{pot})$ raised the grain cadmium content, but the double amount lowered it again to the initial level. On the clay soil liming brought about a decrease in grain cadmium, more clearly at the lower than at the higher fertilizer rate.

The $\mathrm{pH}$ of the soil measured after the harvest was affected by liming only, not by other treatments. The following values were observed:

$\begin{array}{lccc} & \text { no lime } & \begin{array}{c}10 \mathrm{~g} / \text { pot } \\ \mathrm{Ca}(\mathrm{OH})_{2}\end{array} & \begin{array}{c}20 \mathrm{~g} / \mathrm{pot} \\ \mathrm{Ca}(\mathrm{OH})_{2}\end{array} \\ \text { Loam } \ldots \ldots \ldots \ldots \ldots \ldots \ldots & 4.8 & 5.6 & 6.2 \\ \text { Clay } \ldots \ldots \ldots \ldots \ldots \ldots \ldots \ldots \ldots \ldots \ldots \ldots \ldots \ldots \ldots \ldots \ldots & 5.5 & 6.5 & 7.1\end{array}$

\section{Field experiments}

In the experiments performed in 1973 with the small-plot technique, liming affected neither the grain or straw yields nor the elements determined in them. The means over the lime treatments are presented in Table 2.

Table 2. Yields and cadmium contents of spring wheat grain and straw in the small-plot field experiments.

\begin{tabular}{|c|c|c|c|c|}
\hline & \multirow{3}{*}{$\begin{array}{c}\text { Yield } \\
\mathrm{kg} / \mathrm{ha} \\
\text { of D.M. }\end{array}$} & \multicolumn{3}{|c|}{ Cadmium content, $\mu \mathrm{g} / \mathrm{g}$ in D.M. } \\
\hline & & \multirow{2}{*}{$\begin{array}{l}\text { No } \mathrm{Cd} \\
\text { added }\end{array}$} & \multicolumn{2}{|c|}{$\mathrm{Cd}$ added, g/ha } \\
\hline & & & $\overline{100}$ & 200 \\
\hline \multicolumn{5}{|l|}{ 1. Loam soil } \\
\hline 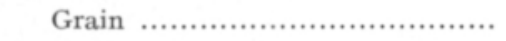 & 990 & $69^{a}$ & $120^{\mathrm{b}}$ & $184^{\mathrm{e}}$ \\
\hline 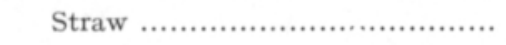 & 1100 & $51^{\mathrm{k}}$ & $151^{1}$ & $231^{\mathrm{m}}$ \\
\hline \multicolumn{5}{|l|}{ 2. Clay soil } \\
\hline 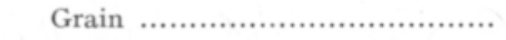 & 2290 & $39^{\mathrm{a}}$ & $67^{b}$ & $65^{b}$ \\
\hline 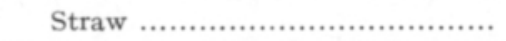 & 2680 & $43 k$ & $66^{\mathrm{k}}$ & $65 k$ \\
\hline
\end{tabular}

Cadmium contents on each soil followed by a common letter do not differ significantly $(\mathrm{P}=0.05)$ according to Tukey's test. 
The grain and straw yields of wheat grown on the loam soil were very low because of severe drought which ripened the crop too early. Nor were the yields in the other experiment on the clay soil high. However, it is obvious that the mineral composition was not highly abnormal as can be seen from the following average contents in grain and straw harvested from the field experiments:

\begin{tabular}{|c|c|c|c|c|}
\hline & $\mathrm{P} \mathrm{mg} / \mathrm{g}$ & $\mathrm{K} \mathrm{mg/g}$ & $\mathrm{Ca} \mathrm{mg/g}$ & $\mathrm{Mg} \mathrm{mg} /$ \\
\hline Loam (1973), grain ............................ & 4.4 & 3.9 & 0.6 & 1.2 \\
\hline,$\quad$ straw $\quad \ldots \ldots \ldots \ldots \ldots \ldots \ldots \ldots \ldots \ldots \ldots \ldots \ldots \ldots$ & 1.6 & 12.1 & 1.8 & 0.8 \\
\hline 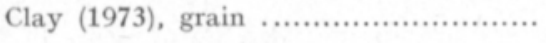 & 3.2 & 3.3 & 0.6 & 1.2 \\
\hline 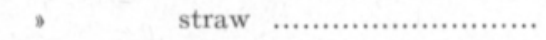 & 1.2 & 9.1 & 1.4 & 0.6 \\
\hline Fine sand (1974), grain ...................... & 3.9 & 4.7 & - & - \\
\hline , straw $\ldots \ldots \ldots \ldots \ldots \ldots$ & 1.1 & 12.8 & - & - \\
\hline
\end{tabular}

Neither grain nor straw yields were affected by the cadmium treatments. Therefore, only the yield means are given in Table 2 .

The cadmium contents of wheat grain and straw were clearly increased by cadmium addition. The contents seemed to increase almost linearly with increasing amounts of cadmium. On the clay soil the response to cadmium addition was much more restricted, and in the case of straw it was not evens ignificant because of wide variation.

The fertilizers containing cadmium in various amounts deriving from different sources did not cause any clear differences in the cadmium contents of wheat grain or straw (Table 3). However, the grain of the wheat given the fertilizer in which the cadmium derived from sulphuric acid, seemed to contain somewhat more cadmium than other grain. It is, however, not certain whether the cadmium treatment is the primary cause, for the yield of this grain was also high. The cadmium content of straw seemed to follow the cadmium supply in the fertilizer in a logical order, but because of wide variation the differences were not significant.

On the basis of the results the most probable increase in the cadmium uptake of the crop due to $49 \mathrm{~g} / \mathrm{ha}$ of cadmium in fertilizer was estimated to be $50 \mathrm{mg} / \mathrm{ha}$ or 0.1 per cent of the supply.

Table 3. Yields and cadmium contents of spring wheat grain and straw in the field experiment in 1974.

\begin{tabular}{|c|c|c|c|c|c|c|}
\hline \multirow[t]{2}{*}{$\left.\mathrm{No}^{1}\right)$} & \multirow{2}{*}{$\begin{array}{l}\text { Source of } \mathrm{P} \\
\text { in fertilizer }\end{array}$} & \multirow{2}{*}{$\begin{array}{c}\text { Amount of } \\
\text { Cd added } \\
\mathrm{g} / \mathrm{ha}\end{array}$} & \multicolumn{2}{|c|}{$\begin{array}{l}\text { Yield, kg/ha } \\
\text { of D.M. }\end{array}$} & \multicolumn{2}{|c|}{$\begin{array}{l}\text { Cadmium content, } \\
\mu \mathrm{g} / \mathrm{kg} \text { in D.M. }\end{array}$} \\
\hline & & & Grain & Straw & Grain & Straw \\
\hline 1. & 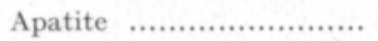 & 1 & 3420 & 3420 & 35 & 48 \\
\hline 2. & 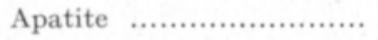 & 18 & 3640 & 3590 & 41 & 55 \\
\hline 3. & Rock phosphate .............. & 34 & 3400 & 3700 & 34 & 56 \\
\hline $\begin{array}{l}4 . \\
5 .\end{array}$ & $\begin{array}{l}\text { Rock phosphate } . . . . . . . . . \\
\text { Apatite }(1)+\text { rock }\end{array}$ & 49 & 3410 & 3070 & 38 & 60 \\
\hline & phosphate (3) & 18 & 3540 & 3670 & 32 & 53 \\
\hline 6. & $\begin{aligned} \text { Apatite }(1)+ & \text { rock } \\
& \text { phosphate }(4)\end{aligned}$ & 18 & 3510 & 3870 & 37 & 55 \\
\hline & Standard error of mean ... & & 55 & 230 & 1.8 & 4.8 \\
\hline
\end{tabular}

1) The number refers to corresponding number in text. 


\section{Discussion}

According to the pot experiment, the soils, loam and clay, did not differ markedly in response to cadmium addition. After similar fertilizer and cadmium treatments the cadmium content of wheat seemed to depend mainly on the soil $\mathrm{pH}$. With the lower fertilizer application on a $\mathrm{pH}$ level of ca. 5.5, which initially existed in the clay and was reached by liming $\left(10 \mathrm{~g} /\right.$ pot $\left.\mathrm{Ca}(\mathrm{OH})_{2}\right)$ in the loam, an addition of $5 \mathrm{mg}$ of cadmium per pot, or $1 \mathrm{mg}$ pre $\mathrm{kg}$ of soil, increased the cadmium content of grain $390-480 \mu \mathrm{g} / \mathrm{g}$. Obviously, the relative effect of the lower cadmium application $(0.5 \mathrm{mg} / \mathrm{pot})$ did not differ markedly. Results of pot experiments with sewage sludge reported by Linnman et al. (1973), as well as ANDERSSON and Nilsson (1976), agree with these results. In a pot experiment of Williams and David (1973), the cadmium content of wheat grain rose about twice as much as expected on the basis of the present results. However, in their experiment the yield was low, and the increase of the cadmium amount in the grain as compared to the amount added to soil, was even lower than in this study.

Increased fertilizer application frequently raised the cadmium contents of wheat grain. Similar observations have been published by JANsson (1975) and ANDERSSon (1976), and in regard to nitrogen fertilization, by Williams and DAvid (1976). The increase was especially marked at the highest cadmium application rate in the limed soils.

The availability to plants of cadmium in acid soils has been shown to decrease with increasing $\mathrm{pH}$ (among others JAAKKOLA and SirÉn 1976). It has been possible to reduce the cadmium uptake of plants by liming (e.g. Jansson 1975, MacLEan 1976). However, in the present experiment the effect of liming was very slight. On the clay soil at the highest cadmium addition, the decrease in the grain cadmium content was clear, even if only at the lower fertilizer level. At the higher fertilizer level, the smaller amount of calcium hydroxide failed to have any effect. The double amount, which raised the $\mathrm{pH}$ to 7.1, decreased the content, although only slightly. On the loam soil at the higher fertilizer level, the smaller amount of lime even raised the grain cadmium content, but the larger amount lowered it again.

The cadmium in connection with fertilizer granules seemed to be more easily available than when it was mixed separately with the soil. The difference was especially clear in the limed loam soil. The different form of cadmium may account for this; the fertilizer was treated with cadmium chloride, while the separate cadmium was given as nitrate. The possibility should be kept in mind that the cadmium content of the fertilizer was not accurate, although this does not seem likely.

In the field experiment on loam, $1000 \mathrm{~kg} / \mathrm{ha}$ of fertilizer containing $100 \mathrm{mg} / \mathrm{kg}$ of cadmium caused the same cadmium content in wheat grain as did $\mathbf{5} \mathbf{g}$ per pot of the same fertilizer. The contents in both grain and straw increased linearly with rising cadmium addition. As stated earlier, the wheat on the loam field was suffering from severe drought. The response to cadmium addition of wheat grown on clay soil was much more restricted. Its cadmium content rose only very slightly and no differences could be observed between the cadmium rates. 
Liming did not affect the cadmium content of wheat grain or straw in field conditions, although both fields were acid and one of them - the loam field even highly acid. One reason for the lacking response of the wheat to liming might lie in an inadequate mixing of the lime with soil. This was performed by harrowing immediately before the fertilizer distribution and sowing.

It is possible that the increase in the cadmium content of wheat on the clay and loam soils due to cadmium addition represents almost the extreme range. An addition of $100 \mathrm{~g} / \mathrm{ha}$ of cadmium raised the cadmium content in grain ca. $10-60 \mu \mathrm{g} / \mathrm{kg}$ and in straw ca. $10-90 \mu \mathrm{g} / \mathrm{kg}$. The results from the experiment on the fine sand agree well with the above figures. According to Williams and DAvid (1976), cadmium accumulated into soil from fertilizer during several years may raise the cadmium content of wheat at an almost equal rate.

In Finland, apatite is mainly utilised as phosphorus raw material for fertilizers. It does not contain cadmium. The cadmium in mineral fertilizers is in general derived from rock phosphate, which is only partly used in Finnish fertilizer manufacture. In no case is it likely, according to data reported by Williams and David (1973) as well as Stenström and Vahter (1974), that the accumulation of cadmium from fertilizers to soil would exceed $20 \mathrm{~g} / \mathrm{ha} / \mathrm{a}$. This would correspond to an increase of $2-12 \mu \mathrm{g} / \mathrm{kg}$ of cadmium in wheat grain. One increase of this magnitude is not considered dangerous according to prevailing opinion (W.H.O. 1972, FrIBERG et al. 1974). However, results published by Williams and David (1976) lead to the conclusion that cadmium accumulated in soil from fertilizers during a period of several years does not lose much of its availability. Continuous use of such fertilizers would, after many years, appear to lead to a marked increase in the cadmium content of grain.

Acknowledgement. The author wishes to express his gratitude to Elintarviketuotannon edisךämissäätiō (the Foundation for Promoting Foodstuff Production) for a grant which made it possible to carry out the experiments. The experimental part of the work was done by the author at the Department of Agricultural Chemistry, University of Helsinki.

\section{REFERENCES}

Andersson, A. 1976. On the influence of manure and fertilizers on the distribution and amounts of plant-available Cd in soils. Swedish J. agric. Res. 6: 27-36.

$\ldots-\&$ Nilsson, K. O. 1976. Influence on the levels of heavy metals in soil and plant from sewage sludge used as fertilizer. Swedish J. agric. Res. 6: 151-159.

Friberg, L., Piscator, M., Nordberg, G. F. \& KJellström, T. 1974. Cadmium in the Environment. 2nd Ed. 248 p. Cleveland.

JАAкKоLA, A. \& Sirén, M. 1976. Factors affecting the availability to radishes of cadmium added to soil. J. Scient. Agric. Soc. Finl. 48: 195-202.

JAnsson, S. L. 1975. Kadmium i växtnäringsbalansen. In NJF, seksjon I. Seminar om tungmetaller, sirkulasjon i jordbruket. 212 p. Ås. p. $24-31$.

Linnman, L., Andersson, A., Nilsson, K. O., Lind, B., KJellström, T. \& Friberg, L. 1973. Cadmium uptake by wheat from sewage sludge used as a plant nutrient source. Arch. Environ. Health 27: 45-47.

MacLean, A. J. 1976. Cadmium in different plant species and its availability in soils as influenced by organic matter and additions of lime, P, Cd and Zn. Can. J. Soil Sci. 56: 129-138.

Steel, R. G. D. \& Torrie, J. H. 1960. Principles and Procedures of Statistics. 481 p. New York. 
Stenström, T. \& VAhter, M. 1974. Cadmium and lead in Swedish commercial fertilizers. Ambio 3: $91-92$.

Williams, C. H. \& David, D. J. 1973. The effect of superphosphate on the cadmium content of soils and plants. Australian J. Soil Res. 11: 43-56.

- - - \& DAvid, D. J. 1976. The accumulation in soil of cadmium residues from phosphate fertilizers and their effect on the cadmium content of plants. Soil Sci. 121: 86-93.

World Health Organization 1972. Evaluation of certain food additives and the contaminants mercury, lead and cadmium. W.H.O. Tech. Rep. Ser. 505. 31 p.

Ms received January 4, 1978

\title{
SELOSTUS
}

\section{Lannoituksen ja kalkituksen vaikutus kevätvehnän kadmiumpitoisuuteen}

\author{
AntTI JАAкKоLA \\ Maatalouden tutkimuskeskus, Maanviljelyskemian ja -fysiikan laitos, 01300 Vantaa
}

Vehnänjyvien kadmiumpitoisuus nousi 55:stä 440-540:een $\mu \mathrm{g} / \mathrm{kg}$, kun astiakokeessa hiueja savimaahan lisättiin kadmiumia $1 \mathrm{mg} / \mathrm{kg}$. Maiden $\mathrm{pH} \mathrm{CaCl} \mathrm{C}_{2}$-lietoksessa oli 5.5. Typpi-, fosfori- ja kaliumlannoitustason kohottaminen lisäsi yleensä jyvien kadmiumpitoisuutta. Kalkituksen vaikutus oli vaihteleva.

Kenttäkokeissa vehnän jyvien ja olkien kadmiumpitoisuus lisäåntyi hiuemaalla paljon enemmän kuin savimaalla. Hiuemaalla kasvanut vehnä kärsi ankarasta kuivuudesta. Kadmiumannos $100 \mathrm{~g} /$ ha nosti jyvien kadmiumpitoisuutta $10-60$ ja olkien $10-90 \mu \mathrm{g} / \mathrm{kg}$ alkuperäisestä tasosta, joka oli jyvissä ja oljissa 39-69 $\mu \mathrm{g} / \mathrm{kg}$. Kokeessa, jossa verrattiin raaka-aineista johtuen kadmiumpitoisuudeltaan erilaisia lannoitteita, ei suurinkaan kadmiumannos, $49 \mathrm{~g} / \mathrm{ha}$, aiheuttanut varmasti havaittavaa jyvien tai olkien kadmiumpitoisuuden muutosta.

Tulosten perusteella voitiin päätellä, että ns. pehmeästä raakafosfaatista valmistettujen lannoitteiden jatkuva käyttö voi johtaa aikaa myöten vehnänjyvien kadmiumpitoisuuden kohoamiseen tasolle, joka nykyisin vallitsevan käsityksen mukaan on haitallinen. 